\title{
Towards a successful translocation of captive slow lorises (Nycticebus spp.) in Borneo: a review and recommendations
}

\author{
C. M. G. van der Sandt
}

Orangutan Project Sdn Bhd., Kuching, Sarawak, Borneo. E-mail: c.v.d.sandt@kpnplanet.nl

\section{ABSTRACT}

Wildlife in Southeast Asia is under threat mainly due to habitat loss and the illegal animal trade. Wild animals are rescued by wildlife centres and the slow loris (Nycticebus spp.) is one of them. After rehabilitation slow lorises are released into the wild and on average $26 \%$ is observed alive after at least ten weeks.

The IUCN has established conditions under which captive wild animals can be translocated into their natural habitat. This review paper aims to give an overview of what has been published on release programs of captive slow lorises in order to improve translocations in Sarawak, Malaysian Borneo. Five documented studies on translocation of slow lorises are summarised. I concentrated on: (1) species of captive slow loris, (2) health check, (3) prerelease habituation, (4) soft or hard release, (5) pre and post-release behavioural observations, (6) assessment of the release area: predators, habitat and protection. The recommendations for future releases are: (1) Study which slow loris species are rehabilitated in Bornean wildlife centres. (2) Study the behaviour of captive slow lorises. (3) Assess the slow loris species in the release area. (4) Study the behaviour and habitat use of the wild population. (5) Assess what predators are present in the release area.

KEY WORDS: reintroduction, prosimian, rehabilitation, conservation.

\section{INTRODUCTION}

In Southeast Asia large numbers of wild animals are rehabilitated in wildlife and rescue centres (Collins et al., 2008; Moore et al., 2014). Wildlife centres care for a.o. orangutans, macaques, slow lorises, wild cats, birds, snakes, turtles, binturongs and sun bears (Isler \& Thorpe, 2003; International Animal Rescue, 2006-2016; Biddle, 2015; pers. obs. CvS, 20092015). In the wild, Bornean animal species are threatened in different ways; animals are captured to be sold and kept as pets or used in traditional medicines (Shepherd et al., 2004) and rainforest is converted to farmland and oil palm plantations (Nekaris \& Starr, 2015). Wild animals cannot survive in these new habitats. They are killed or are caught and sold (Shepherd et al., 2004). It is illegal to catch and keep many of the wild Bornean animal species and captive animals are confiscated by the government and transferred to wildlife centres. Furthermore, the centres are also offered captive wild animals, which were purchased in animal markets by local people or tourists and are no longer wanted (pers. obs. CvS, 2015). The aim of wildlife centres is to rehabilitate the animals and, if possible, release them back into the wild (Biddle, 2015; Nekaris \& Starr, 2015). The International Union for 
Conservation of Nature (IUCN) has established conditions under which captive wild animals can be released or translocated into their natural habitat (IUCN, 2002; IUCN/SSC, 2013). According to the IUCN, translocation is "the human-mediated movement of living organisms from one area, with release in another".

\section{The slow loris}

The slow loris (Nycticebus spp.) is a small nocturnal strepsirrhine primate from Southeast Asia. The average weight of an adult slow loris is between 265 and 1150 grams, depending on the species (Nekaris, 2014). They have a round head and large forward-facing eyes. The arms and legs are adapted to an arboreal life. Slow lorises are the only venomous primates; they have a brachial gland that produces a secretion which is toxic when licked by the slow loris and mixed with saliva. The bite is poisonous to other animals (Ligabue-Braun et al., 2012; Rode-Margono \& Nekaris, 2015). Despite their protected status, slow lorises are widely caught and sold in markets throughout Southeast Asia. They are very popular as pets and are used in traditional medicines (Nekaris \& Starr, 2015).

Nine species of slow loris have been identified (Nekaris et al., 2014): The Bengal slow loris ( $N$. bengalensis Lacépède), Sunda or greater slow loris ( $N$. coucang Boddaert), Hiller's slow loris (N. hilleri Stone \& Rehn), Javan slow loris (N. javanicus É. Geoffroy) and pygmy slow loris (N. pygmaeus Bonhote). Recently four Bornean species of slow loris have been recognized: Sody's slow loris (N. bancanus Lyon), Bornean slow loris (N. borneanus Lyon), Kayan River slow loris (N. kayan Munds, Nekaris \& Ford) and Philippine slow loris ( $N$. menagensis Lydekker) (Munds et al., 2013). Different species of slow loris are kept in wildlife centres. It is hard to keep slow lorises in captivity for a long period, due to incurred stress, their nocturnal lifestyle and their diet (Beckerson, 2015; Nekaris \& Starr, 2015). If released into their natural habitat, many of the slow lorises do not survive for a very long time (Moore et al., 2014; Biddle, 2015; Nekaris \& Starr, 2015).

\section{Slow lorises in Matang Wildlife Centre, Malaysian Borneo}

Since 2009 there have been 29 documented arrivals of slow lorises at Matang Wildlife Centre. Seven of these arrivals were released within two to three days, and four within two to four months (reference date April 2017) (Beckerson, 2016; Browning, 2017). Matang is part of Kubah National Park, Sarawak, Malaysia. Kubah, 15 km northwest of Kuching, is 22 sq. $\mathrm{km}$ in size. The bulk of the park is a sandstone plateau at an elevation between 150 and $450 \mathrm{~m}$ asl and it has five main vegetation types: riverine forest, lowland mixed dipterocarp forest, kerangas (heath) forest, submontane forest and secondary forest. 


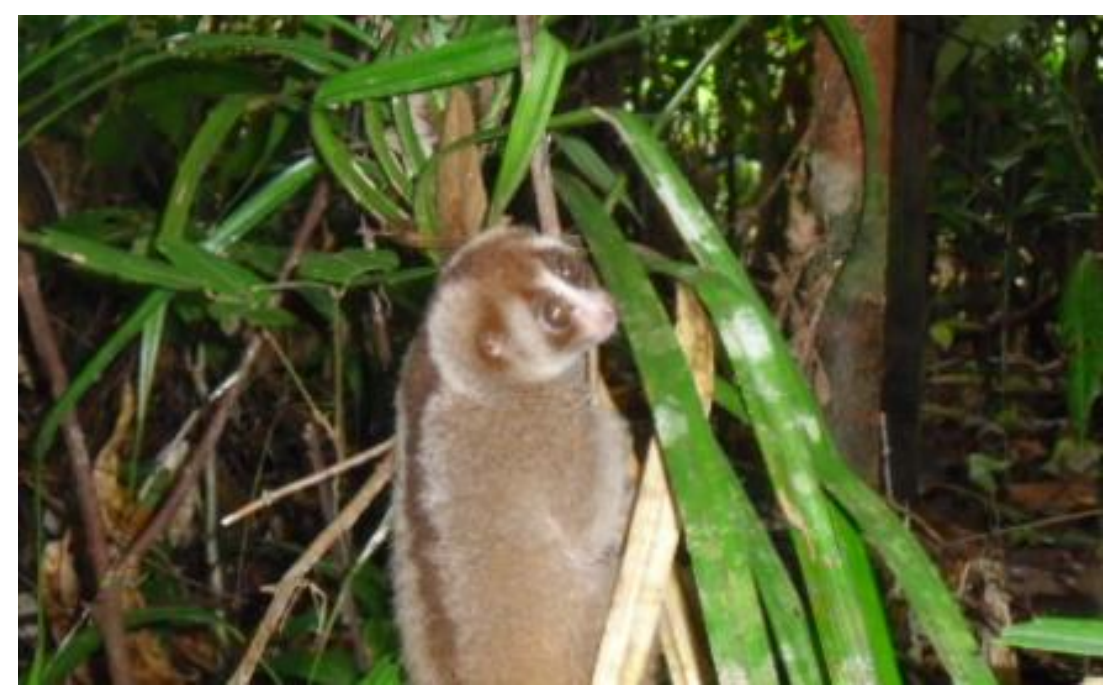

Fig. 1 Slow loris in Matang Wildlife Centre (Aug 2009) Photo: Carola Voigt

In this paper I aim to give an overview of what has been published (reference date August 2016) on rehabilitation and release programs of captive slow lorises, in order to increase the number of future successful translocations in Sarawak, Malaysian Borneo. The four main questions of this review paper are:

(1) Which slow loris species have been studied? Nine slow loris species have been described (Nekaris et al.,2014). Although there are some overlaps, these species are found in different areas and habitats and have different feeding requirements and behaviour. It is important to know the species of captive slow loris, in order to supply the animals with the most suitable food during rehabilitation and to assess the area and habitat where the lorises will be released.

(2) What pre-and post-conditions for release have to be met for the best possible success for survival after release? As the main objective of this paper is to identify the preconditions to increase the number of future successful translocations, it is important to know which preconditions researchers have used, in relation to the percentage of surviving animals (for any length of time) in their studies. This argument leads to the following questions:

(3)What percentage of slow lorises did survive after release?

(4)What recommendations did the researchers make for future research? The release of slow lorises faces many challenges. The recommendations of previous studies might help to improve the results of future translocations. 


\section{METHODS}

Literature was collected between February and May 2016. Online data bases were searched for articles, books and doctoral theses in English: Conservation database for lorises (Loris, Nycticebus) and pottos (Arctocebus, Perodicticus), prosimian primates; Elsevier Science Direct; Google Scholar. A web search was carried out with the following keywords: slow loris, captive slow loris, conservation, rehabilitation, translocation, reintroduction, primates. The snowball method was used. L. Biddle and N. Beckerson, respectively founder and manager of the Orangutan Project, based in Matang Wildlife Centre, Sarawak, Malaysia, answered questions for clarification of results found, both in person and via email. This paper is a review of documented research on rehabilitation and release of captive wild-born slow lorises, in accordance with the IUCN Guidelines. The IUCN issued two guidelines on translocations and reintroductions: Guidelines for nonhuman primate re-introductions (2002); Guidelines for Reintroductions and Other Conservation Translocations (2013). The regulations in these documents that are within the scope of this paper include: (1) Basic biology of the species, biotic and abiotic habitat needs, interspecific relationships; (2) Quarantine before release; (3) Welfare of the captive animal to avoid stress during rehabilitation, handling and transport; (4) Health and behaviour, both of the captive animal that is going to be released and of the wild population in the release area; (5) Assessment of suitable release habitat, niches of the translocated species; (6) The season of release; (7) Pre- and post-release monitoring of the animals and the release site.

The use of the following terms in this paper is based on the IUCN Guidelines and Moore et al.(2014). Release: a general term to indicate the process of release into the wild, rehabilitation and monitoring excluded. Translocation: the human-mediated movement of living organisms from one area, with release in another. Conservation translocation: a translocation to reinforce an existing population of conspecifics. Reintroduction: the reintroduction of a species into an area which was once part of its range, but from which it has been extirpated or become extinct.

The last decade has seen an increasing number of slow lorises released by wildlife centres. Many of the slow lorises have simply been released into any suitable habitat in the surroundings of the centre without a thorough health check, species study or knowledge of their ability to survive in the wild (Streicher, 2004; Moore et al., 2014; Nekaris \& Starr, 2015). These often unpublished incidences of release are not included in this paper. 


\section{RESULTS}

The first question was which slow loris species have been studied and what was the number of translocated animals. Table 1 shows five documented studies of three slow loris species: the Javan slow loris (Nycticebus javanicus), pygmy slow loris (N. pygmaeus) and Sunda or greater slow loris ( $N$. coucang). The number of translocated slow lorises in the five studies ranges from 5 to 18 specimens.

Table 1 Documented translocation studies of captive wild-born slow lorises (Nycticebus spp.) in Indonesia and Vietnam

\begin{tabular}{|c|c|c|c|c|c|}
\hline References & $\begin{array}{l}\text { Slow loris } \\
\text { species }\end{array}$ & $\begin{array}{l}\text { Number of } \\
\text { translocated } \\
\text { slow lorises }\end{array}$ & $\begin{array}{l}\text { Rehabilitation } \\
\text { Centre }\end{array}$ & $\begin{array}{l}\text { Translocation } \\
\text { area }\end{array}$ & $\begin{array}{l}\text { Type of } \\
\text { translocation }\end{array}$ \\
\hline $\begin{array}{l}\text { Streicher, U. } \\
2003,2004\end{array}$ & $\begin{array}{l}\text { Pygmy slow } \\
\text { loris ( } N . \\
\text { pygmaeus) }\end{array}$ & $\begin{array}{l}9 \text { captive wild- } \\
\text { born }\end{array}$ & $\begin{array}{l}\text { Endangered } \\
\text { Primate Rescue } \\
\text { Centre, Cuc } \\
\text { Phuong National } \\
\text { Park, Vietnam }\end{array}$ & $\begin{array}{l}\text { Former botanical } \\
\text { garden of Cuc } \\
\text { Phuong National } \\
\text { Park, Vietnam }\end{array}$ & Reintroduction \\
\hline $\begin{array}{l}\text { Collins, R. } \\
2008\end{array}$ & $\begin{array}{l}\text { Sunda or } \\
\text { greater slow } \\
\text { loris } \\
\text { (N. coucang) }\end{array}$ & $\begin{array}{l}7 \text { ( } 3 \text { juveniles), } \\
\text { captive wild- } \\
\text { born }\end{array}$ & $\begin{array}{l}\text { Pusat } \\
\text { Penyelamatan } \\
\text { Satwa, Lampung, } \\
\text { Sumatra, } \\
\text { Indonesia } \\
\end{array}$ & $\begin{array}{l}\text { Batutegi Reserve, } \\
\text { Sumatra, } \\
\text { Indonesia }\end{array}$ & Reintroduction \\
\hline $\begin{array}{l}\text { Moore, R.S. } \\
2012,2014\end{array}$ & $\begin{array}{l}\text { Javan slow loris } \\
\text { (N. javanicus) }\end{array}$ & $\begin{array}{l}18 \text { captive } \\
\text { wild-born (6\% } \\
\text { captive } \\
\text { born?)* }\end{array}$ & $\begin{array}{l}\text { Ciapus Primate } \\
\text { Centre, Java, } \\
\text { Indonesia }\end{array}$ & $\begin{array}{l}\text { Gunung } \\
\text { Halimum-Salak } \\
\text { National Park, } \\
\text { Java, Indonesia }\end{array}$ & $\begin{array}{l}\text { Reintroduction } \\
(2012) \\
\text { Conservation } \\
\text { translocation } \\
(2014)\end{array}$ \\
\hline $\begin{array}{l}\text { Kenyon, M. } \\
2014\end{array}$ & $\begin{array}{l}\text { Pygmy slow } \\
\text { loris (N. } \\
\text { pygmaeus) }\end{array}$ & $\begin{array}{l}13 \text { captive } \\
\text { wild-born }\end{array}$ & $\begin{array}{l}\text { Dao Tien } \\
\text { Endangered } \\
\text { Primate Species } \\
\text { Centre, Vietnam }\end{array}$ & $\begin{array}{l}\text { Dong Nai } \\
\text { Biosphere } \\
\text { Reserve, Vietnam }\end{array}$ & Reintroduction \\
\hline $\begin{array}{l}\text { Moore, R.S. } \\
2014\end{array}$ & $\begin{array}{l}\text { Sunda or } \\
\text { greater slow } \\
\text { loris } \\
\text { (N. coucang) }\end{array}$ & $\begin{array}{l}5 \text { captive wild- } \\
\text { born ( } 6 \% \\
\text { captive } \\
\text { born?) }\end{array}$ & $\begin{array}{l}\text { Ciapus Primate } \\
\text { Centre, Java, } \\
\text { Indonesia }\end{array}$ & $\begin{array}{l}\text { Batutegi Reserve, } \\
\text { Sumatra, } \\
\text { Indonesia }\end{array}$ & $\begin{array}{l}\text { Conservation } \\
\text { translocation }\end{array}$ \\
\hline
\end{tabular}

* Between 2008 and 2011 Ciapus Primate Centre received 180 slow lorises with $6 \%$ captive born. No details of species of the captive born are mentioned.

Moore (2014) states that over $85 \%$ of the confiscated animals in his study were unsuitable for release. In many captive lorises, the teeth are cut or removed before confiscation to prevent the lorises from biting during handling in animal markets. All slow loris species are obligate gum eaters (Nekaris, 2014). Gum is acquired by the gouging of tree bark. Slow lorises without teeth will never be able to gouge for gum, so are unsuitable for release. Stress and very poor living conditions before entering the rescue centres are also causes of permanent physical and behavioural damage. This results in a low number of animals suitable for translocation. The authors describe their releases as reintroductions or conservation translocations. The second and third questions concerned the pre- and postconditions for release and the percentage of surviving slow lorises after release. 
Table 2 summarizes the pre-release preconditions during rehabilitation and the percentage of animals that survived after release.

Table 2 Slow lorises (Nycticebus spp.) pre-release conditions and post-release survival

\begin{tabular}{|c|c|c|c|c|c|c|c|}
\hline References & $\begin{array}{l}\text { Slow loris } \\
\text { species }\end{array}$ & $\begin{array}{l}\text { Alive/unkown*/dead } \\
\text { animals after } \\
\text { translocation }\end{array}$ & $\begin{array}{l}\text { Healthcheck and } \\
\text { treatment }\end{array}$ & $\begin{array}{l}\text { Period of ex } \\
\text { situ** pre- } \\
\text { release } \\
\text { habituation } \\
\text { (weeks) and } \\
\text { type of cage }\end{array}$ & $\begin{array}{l}\text { Period of in } \\
\text { situ** pre- } \\
\text { release } \\
\text { habituation } \\
\text { (days) and type } \\
\text { of cage }\end{array}$ & $\begin{array}{l}\text { Soft or hard } \\
\text { release } * * *\end{array}$ & $\begin{array}{l}\text { Behavioural } \\
\text { observations } \\
\text { during habituation } \\
\text { period }\end{array}$ \\
\hline $\begin{array}{l}\text { Streicher, U. } \\
2003,2004\end{array}$ & $\begin{array}{l}\text { Pygmy slow } \\
\text { loris (N. } \\
\text { pygmaeus) }\end{array}$ & $\begin{array}{l}\text { Alive } 4 \text { animals } 44.4 \% \\
\text { Unknown } 1 \text { animal } 11.2 \% \\
\text { after } 1 \text { day } \\
\text { Dead } 4 \text { animals } 44.4 \%\end{array}$ & $\begin{array}{l}\text { Health examinations, } \\
\text { tuberculosis test, } \\
\text { parasite medication }\end{array}$ & $\begin{array}{l}\text { Six weeks } \\
\text { quarantine }\end{array}$ & $\begin{array}{l}\text { "A few days" in } \\
\text { small habituation } \\
\text { cages }\end{array}$ & Soft release & $x$ \\
\hline $\begin{array}{l}\text { Collins, R. } \\
2008\end{array}$ & $\begin{array}{l}\text { Sunda or } \\
\text { Greater slow } \\
\text { loris } \\
\text { (N. coucang) }\end{array}$ & $\begin{array}{l}\text { No data, period of post- } \\
\text { release monitoring lasted one } \\
\text { night }\end{array}$ & $\begin{array}{l}\text { Health examinations, } \\
\text { weight, tuberculosis } \\
\text { test, parasite } \\
\text { medication }\end{array}$ & $\begin{array}{l}\text { Min. six weeks } \\
\text { quarantine }\end{array}$ & $\begin{array}{l}\text { Two days in small } \\
\text { bamboo cage } \\
(1.3 \times 1.6 \times 1.0 \mathrm{~m}) \\
\text { with } 10 \mathrm{~m} \\
\text { bamboo \& } \\
\text { netting extension }\end{array}$ & Soft release & $\begin{array}{l}\text { Natural nesting } \\
\text { behaviour, social } \\
\text { behaviour, foraging } \\
\text { with woundgouging } \\
\text { and hunting, } \\
\text { locomotion, } \\
\text { substrate use, } \\
\text { sequences of play } \\
\text { fighting (juveniles) }\end{array}$ \\
\hline $\begin{array}{l}\text { Moore, R.S . } \\
2012,2014\end{array}$ & $\begin{array}{l}\text { Javan slow } \\
\text { loris } \\
\text { (N. javanicus) }\end{array}$ & $\begin{array}{l}\text { Alive } 5 \text { animals 27.8\%, after } \\
241.6+\text { days (mean) } \\
\text { Unknown } 5 \text { animals } 27.8 \% \\
\text { after } 286.4 \text { days (mean) } \\
\text { Back to centre } 1 \text { animal } 5.5 \% \\
\text { after } 148 \text { days } \\
\text { Dead } 7 \text { animals } 38.9 \% \text { after } \\
38.4 \text { days (mean) }\end{array}$ & $\begin{array}{l}\text { Health examinations, } \\
\text { dental state, } \\
\text { behavioural } \\
\text { assessment: natural } \\
\text { behaviour }\end{array}$ & $\begin{array}{l}\text { Min. six weeks } \\
\text { quarantine }\end{array}$ & $\begin{array}{l}19.9 \text { days (mean) } \\
\text { small cage } \\
66.7 \text { days (mean) } \\
\text { soft release } \\
\text { enclosure }\end{array}$ & $\begin{array}{l}\text { Soft release: } \\
\text { from large } \\
\text { enclosure } 9 \\
\text { animals; from } \\
\text { small cage } 7 \\
\text { animals } \\
\text { Hard release } 2 \\
\text { animals }\end{array}$ & $\begin{array}{l}\text { Behavioural } \\
\text { assessment, } \\
\text { vocalizing, social } \\
\text { interaction, } \\
\text { substrate use, } \\
\text { locomotion, } \\
\text { foraging behaviour, } \\
\text { gouging }\end{array}$ \\
\hline $\begin{array}{l}\text { Kenyon, M. } \\
2014\end{array}$ & $\begin{array}{l}\text { Pygmy slow } \\
\text { loris (N. } \\
\text { pygmaeus) }\end{array}$ & $\begin{array}{l}\text { Alive } 4 \text { animals } 30.8 \% \text {, after } \\
65+\text { days (mean) } \\
\text { Unknown } 3 \text { animals } 23.0 \% \\
\text { after } 9.7 \text { days (mean) }\end{array}$ & $\begin{array}{l}\text { Health examinations, } \\
\text { weight, blood sample, } \\
\text { dental state, } \\
\text { tuberculosis test, sex, }\end{array}$ & $\begin{array}{l}\text { Six weeks } \\
\text { quarantine and } \\
\text { four weeks in } \\
\text { small cage or }\end{array}$ & $\begin{array}{l}\text { Two days to > two } \\
\text { months }\end{array}$ & $\begin{array}{l}\text { Soft release } 8 \\
\text { animals } \\
\text { Hard release } 5\end{array}$ & $\begin{array}{l}\text { Foraging behaviour, } \\
\text { gouging, climbing, } \\
\text { moving between } \\
\text { sleeping sites }\end{array}$ \\
\hline
\end{tabular}




\begin{tabular}{|c|c|c|c|c|c|c|c|}
\hline & & $\begin{array}{l}\text { Back to centre } 1 \text { animal } 7.7 \% \\
\text { after } 22 \text { days } \\
\text { Dead } 5 \text { animals } 38.5 \% \text { after } 21 \\
\text { days (mean) }\end{array}$ & $\begin{array}{l}\text { estimated age, } \\
\text { assessment of } \\
\text { stereotypic behaviour, } \\
\text { microchip implant, } \\
\text { parasite medication }\end{array}$ & $\begin{array}{l}\text { semiforested } \\
\text { enclosure in } \\
\text { centre }\end{array}$ & & animals & \\
\hline $\begin{array}{l}\text { Moore, R.S. } \\
2014\end{array}$ & $\begin{array}{l}\text { Sunda or } \\
\text { greater slow } \\
\text { loris } \\
\text { (N. coucang) }\end{array}$ & $\begin{array}{l}\text { Alive } 0 \text { animals } \\
\text { Unknown } 1 \text { animal } 20 \% \text { after } \\
146 \text { days } \\
\text { Dead } 4 \text { animals } 80 \% \text { after } \\
128.8 \text { days (mean) }\end{array}$ & $\begin{array}{l}\text { Health examinations, } \\
\text { dental state, natural } \\
\text { behaviour } \\
\text { assessment }\end{array}$ & $\begin{array}{l}\text { Min. six weeks } \\
\text { quarantine }\end{array}$ & 6 days small cage & $\begin{array}{l}\text { Soft release } 5 \\
\text { animals }\end{array}$ & $\begin{array}{l}\text { Behavioural } \\
\text { assessment, } \\
\text { vocalizing, social } \\
\text { interaction, } \\
\text { substrate use, } \\
\text { locomotion, } \\
\text { foraging behaviour, } \\
\text { gouging }\end{array}$ \\
\hline
\end{tabular}

*Unknown: animals lose their collar or disappear after a period of time and are not found dead.

**Ex situ: habituation cage in the rescue centre. In situ: pre-release cage in the release area.

$* * *$ Soft release: after a period of minimal six weeks in a rehabilitation centre the slow lorises are transferred to a cage in the translocation area (in situ) from which they are released after a few days up to over two months. Hard release: after a few days or weeks in a rehabilitation centre (ex situ cages) the slow lorises are released in the translocation area without additional feeding.

$x$ not mentioned in the article 
Survival rates are between 0 and 44.4\%. In Kenyon's study (2014) four animals survived. They all had a soft release. When hard released the fate of the animals is unknown or the animals died. The pre-release preconditions matched most of the guidelines of the IUCN (2002, 2013): (1) A health check of the captive animals was done in all studies. As stated above, the dental state of slow lorises is important. In one study no check of dental state or referral to ability to gouge is mentioned. However, after release tree gouging was observed and the thesis stresses the importance of the toothcomb in the lower jaw (Streicher, 2004); (2) Quarantine periods of a minimum of six weeks is mentioned in all studies; (3) Welfare of the captive animals to avoid stress was guaranteed by pre-release habituation. There are differences between the studies: from ex situ habituation in small cages and a subsequent hard release, to ex situ and in situ habituation in semi forested enclosures (soft release); (4) Behavioural observations during the pre-release habituation period is mentioned in four studies. The success of a translocation project can be measured by the number of animals surviving in a given period.

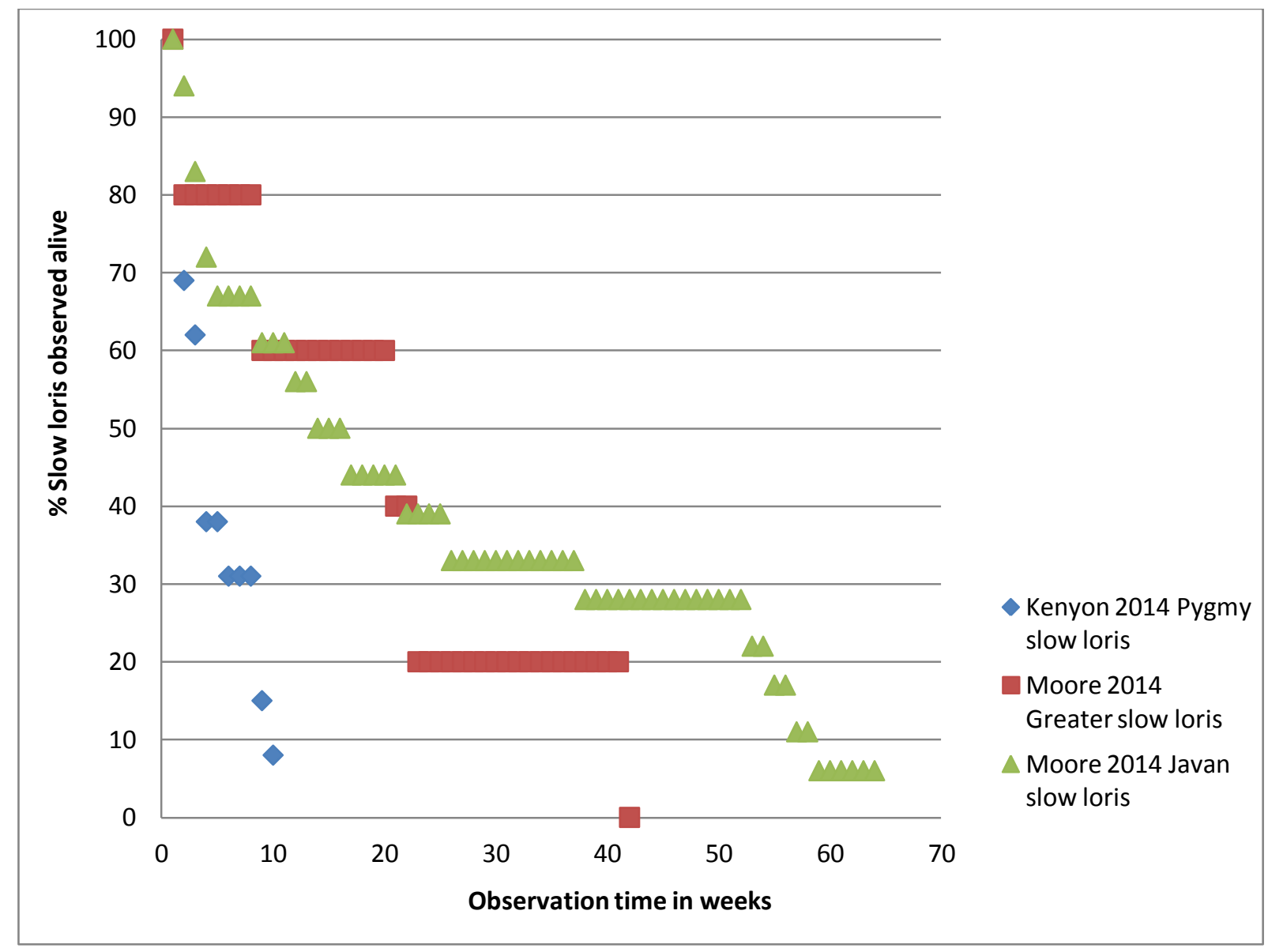

Fig. 2 Percentage slow loris survival in observation period

Figure 2 summarises the percentage of surviving slow lorises during the observation period in three studies (Kenyon, 2014; Moore, 2012; Moore et al., 2014). In two studies no detailed information on this topic is available or applicable (Streicher, 2003; Collins, 2008). 
Table 3 shows an overview of the pre-release habitat preconditions and the post-release survival of slow lorises.

Table 3 Pre-release preconditions of the translocation area and post-release survival of slow lorises

\begin{tabular}{|c|c|c|c|c|c|c|c|c|}
\hline References & Slow loris species & $\begin{array}{l}\text { Alive/unk } \\
\text { after tran }\end{array}$ & $\begin{array}{l}\text { In*/dead a } \\
\text { cation }\end{array}$ & nimals & $\begin{array}{l}\text { Existing population } \\
\text { of } \\
\text { slow lorises in } \\
\text { translocation area }\end{array}$ & $\begin{array}{l}\text { Assessment } \\
\text { of predators } \\
\text { in } \\
\text { translocation } \\
\text { area } \\
\end{array}$ & $\begin{array}{l}\text { Habitat/vegetation } \\
\text { assessment }\end{array}$ & $\begin{array}{l}\text { Protection } \\
\text { translocation } \\
\text { area }\end{array}$ \\
\hline $\begin{array}{l}\text { Streicher, U. } \\
2003,2004\end{array}$ & $\begin{array}{l}\text { Pygmy slow loris } \\
\text { (N. pygmaeus) }\end{array}$ & $\begin{array}{l}\text { Alive } \\
\text { Unknown } \\
\text { Dead }\end{array}$ & $\begin{array}{l}4 \text { animals } \\
1 \text { animal } \\
4 \text { animals }\end{array}$ & $\begin{array}{l}44.4 \% \\
11.2 \% \\
44.4 \% \\
\end{array}$ & $\begin{array}{l}\text { One resident pygmy } \\
\text { slow loris in } 1999\end{array}$ & $x$ & Dense vegetation & National park \\
\hline Collins, R. 2008 & $\begin{array}{l}\text { Sunda or greater } \\
\text { slow loris } \\
\text { (N. coucang) }\end{array}$ & $\begin{array}{l}\text { No data, } \mathrm{p} \\
\text { monitoring }\end{array}$ & $\begin{array}{l}\text { d of post-re } \\
\text { sted one nig }\end{array}$ & lease & $\begin{array}{l}\text { "Low abundance of } \\
\text { lorises" in } 2006\end{array}$ & $x$ & $x$ & $\begin{array}{l}\text { Limited human } \\
\text { impact, high level } \\
\text { of protection by } \\
\text { Forest } \\
\text { Department }\end{array}$ \\
\hline $\begin{array}{l}\text { Moore, R.S. } \\
2012,2014\end{array}$ & $\begin{array}{l}\text { Javan slow loris } \\
\text { (N. javanicus) }\end{array}$ & $\begin{array}{l}\text { Alive } \\
\text { Unknown } \\
\text { Dead } \\
\text { Back to ce }\end{array}$ & $\begin{array}{l}5 \text { animals } \\
5 \text { animals } \\
7 \text { animals } \\
1 \text { animal }\end{array}$ & \begin{tabular}{r|}
$27.8 \%$ \\
$27.8 \%$ \\
$38.9 \%$ \\
$5.5 \%$ \\
\end{tabular} & $\begin{array}{l}\text { Assessment of slow } \\
\text { lorises in } 2007,2011\end{array}$ & $x$ & Habitat assessment & National park \\
\hline Kenyon, M. 2014 & $\begin{array}{l}\text { Pygmy slow loris } \\
\text { (N. pygmaeus) }\end{array}$ & $\begin{array}{l}\text { Alive } \\
\text { Unknown } \\
\text { Dead } \\
\text { Back to ce }\end{array}$ & $\begin{array}{l}4 \text { animals } \\
3 \text { animals } \\
5 \text { animals } \\
1 \text { animal }\end{array}$ & $\begin{array}{r}30.8 \% \\
23.0 \% \\
38.5 \% \\
7.7 \%\end{array}$ & $\begin{array}{l}\text { Assessment of pygmy } \\
\text { lorises in one release } \\
\text { site (Cat Tien National } \\
\text { Park), not in Vinh Cuu } \\
\text { Biosphere Reserve }\end{array}$ & $\begin{array}{l}\text { Estimation of } \\
\text { predator } \\
\text { density }\end{array}$ & $\begin{array}{l}\text { Forest connectivity, } \\
\text { percentage of } \\
\text { ground cover, tree } \\
\text { occupation }\end{array}$ & National park \\
\hline Moore, R.S. 2014 & $\begin{array}{l}\text { Sunda or greater } \\
\text { slow loris } \\
\text { (N. coucang) }\end{array}$ & $\begin{array}{l}\text { Alive } \\
\text { Unknown } \\
\text { Dead }\end{array}$ & $\begin{array}{l}0 \text { animals } \\
1 \text { animal } \\
4 \text { animals }\end{array}$ & $\begin{array}{c}20 \% \\
80 \%\end{array}$ & $\begin{array}{l}\text { Assessment of slow } \\
\text { lorises }\end{array}$ & $x$ & Habitat assessment & National reserve \\
\hline
\end{tabular}

*Unknown: animals may lose their collar or disappear after a period of time and are not found dead.

$x$ not mentioned in the article 
(5) An assessment of an existing population of slow lorises in the translocation area is done in all but one translocation area where permission was withheld by the local authorities (Kenyon et al., 2014); (6) The assessment of predators in the translocation area is listed separately in the present paper as it is of significant importance (pers. obs. CvS, 2015). Four studies do not mention a pre-release assessment of predators, although they were present in the release area. In one study the attack of slow lorises by snakes and probably a raptor in the release area is observed (Moore et al., 2014). In Streicher's study two lorises were killed by predators, one of which was a marbled cat (Streicher \& Nadler, 2003). (7) An assessment of the vegetation is carried out in four studies and all translocation areas are within national parks, so a reasonable level of protection must be assumed. Table 4 is a summary of the post-release monitoring of slow lorises related to the surviving animals.

Table 4 Post-release preconditions and post-release survival of slow lorises: the animals

\begin{tabular}{|c|c|c|c|c|c|}
\hline References & $\begin{array}{l}\text { Slow loris } \\
\text { species }\end{array}$ & $\begin{array}{l}\text { Alive/unkowr } \\
\text { after transloc }\end{array}$ & $\begin{array}{l}* \text { /dead animals } \\
\text { ation }\end{array}$ & $\begin{array}{l}\text { Period of post- } \\
\text { release } \\
\text { monitoring } \\
\text { (days) }\end{array}$ & $\begin{array}{l}\text { Observations } \\
\text { during post } \\
\text { release } \\
\text { monitoring }\end{array}$ \\
\hline $\begin{array}{l}\text { Streicher, U. } \\
2003,2004\end{array}$ & $\begin{array}{l}\text { Pygmy slow } \\
\text { loris ( } N . \\
\text { pygmaeus) }\end{array}$ & $\begin{array}{l}\text { Alive } \\
\text { Unknown } \\
\text { Dead }\end{array}$ & $\begin{array}{lc}\text { animals } & 44.4 \% \\
1 \text { animal } & 11.2 \% \\
4 \text { animals } & 44.4 \%\end{array}$ & $\begin{array}{l}\text { Radio telemetry } \\
\text { and direct } \\
\text { observation 134+ } \\
\text { days }\end{array}$ & $\begin{array}{l}\text { Use of sleeping } \\
\text { sites, movements, } \\
\text { substrate use, } \\
\text { range distance, } \\
\text { fouraging, gouging, } \\
\text { social behaviour, } \\
\text { vocalisations }\end{array}$ \\
\hline $\begin{array}{l}\text { Collins, R. } \\
2008\end{array}$ & $\begin{array}{l}\text { Sunda or } \\
\text { greater slow } \\
\text { loris } \\
\text { (N. coucang) }\end{array}$ & $\begin{array}{l}\text { No data, perioc } \\
\text { monitoring last }\end{array}$ & $\begin{array}{l}\text { d of post-release } \\
\text { ed one night }\end{array}$ & $\begin{array}{l}\text { Direct } \\
\text { observation, one } \\
\text { night }\end{array}$ & $\begin{array}{l}\text { Behaviour: } \\
\text { playfighting, } \\
\text { allogrooming, } \\
\text { independent } \\
\text { behaviour of } \\
\text { juveniles }\end{array}$ \\
\hline $\begin{array}{l}\text { Moore, R.S. } \\
2012,2014\end{array}$ & $\begin{array}{l}\text { Javan slow loris } \\
\text { (N. javanicus) }\end{array}$ & $\begin{array}{l}\text { Alive } \\
\text { Unknown } \\
\text { Dead } \\
\text { Back to centre }\end{array}$ & $\begin{array}{lr}\mathbf{5} \text { animals } & \mathbf{2 7 . 8 \%} \\
5 \text { animals } & 27.8 \% \\
7 \text { animals } & 38.9 \% \\
1 \text { animal } & 5.5 \%\end{array}$ & $\begin{array}{l}\text { Radio telemetry } \\
\text { and direct } \\
\text { observation } \\
155.5 \text { days } \\
\text { (mean) }\end{array}$ & $\begin{array}{l}\text { Behavioural } \\
\text { assessment, } \\
\text { vocalizing, social } \\
\text { interaction, } \\
\text { substrate use, } \\
\text { locomotion, } \\
\text { foraging behaviour, } \\
\text { gouging }\end{array}$ \\
\hline $\begin{array}{l}\text { Kenyon, M. } \\
2014\end{array}$ & $\begin{array}{l}\text { Pygmy slow } \\
\text { loris ( } N . \\
\text { pygmaeus) }\end{array}$ & $\begin{array}{l}\text { Alive } \\
\text { Unknown } \\
\text { Dead } \\
\text { Back to centre }\end{array}$ & $\begin{array}{lr}4 \text { animals } & \mathbf{3 0 . 8 \%} \\
3 \text { animals } & 23.0 \% \\
5 \text { animals } & 38.5 \% \\
1 \text { animal } & 7.7 \%\end{array}$ & $\begin{array}{l}\text { Radio telemetry } \\
\text { and direct } \\
\text { observation, max } \\
73 \text { days }\end{array}$ & $\begin{array}{l}\text { Height of sleeping } \\
\text { place in trees, } \\
\text { distance between } \\
\text { sleeping sites, start } \\
\text { of evening activities }\end{array}$ \\
\hline $\begin{array}{l}\text { Moore, R.S. } \\
2014\end{array}$ & $\begin{array}{l}\text { Sunda or } \\
\text { greater slow } \\
\text { loris } \\
\text { (N. coucang) }\end{array}$ & $\begin{array}{l}\text { Alive } \\
\text { Unknown } \\
\text { Dead }\end{array}$ & $\begin{array}{l}0 \text { animals } \\
1 \text { animal } 20 \% \\
4 \text { animals } 80 \%\end{array}$ & $\begin{array}{l}\text { Radio telemetry } \\
\text { and direct } \\
\text { observation } \\
132.2 \text { days } \\
\text { (mean) }\end{array}$ & $\begin{array}{l}\text { Behavioural } \\
\text { assessment, } \\
\text { vocalizing, social } \\
\text { interaction, } \\
\text { substrate use, } \\
\text { locomotion, } \\
\text { foraging behaviour, } \\
\text { gouging }\end{array}$ \\
\hline
\end{tabular}


*Unknown: animals may lose their collar or disappear after a period of time and are not found dead.

(8) In one study post-release monitoring lasted only one night, due to local customs regarding entering the forest at night and communication on ecological issues with local workers (Collins et al., 2008); (9) In all studies post-release behaviour of the slow lorises is studied. Four studies used direct observation and radio telemetry. In one of the translocations no radio telemetry was applied (Collins et al., 2008); (10) A health check of resident slow lorises is not applied in any of the studies. The IUCN guidelines of 2013 however, stress the importance of an assessment of the health of wild populations. Regarding the final research question on recommendations, Table 5 summarizes the recommendations for future research as mentioned by the cited authors. Also included are suggestions presented in an overview paper on conservation and ecology of slow lorises by Nekaris and Starr (2015).

Table 5 Recommendations for future research on rehabilitation and translocation of slow lorises

\begin{tabular}{|c|c|c|}
\hline References & Slow loris spp. & Pre-release recommendations \\
\hline $\begin{array}{l}\text { Streicher, U. } 2004 \\
\text { Collins, R. } 2008\end{array}$ & $\begin{array}{l}\text { Pygmy slow loris } \\
\text { Sunda or greater slow } \\
\text { loris }\end{array}$ & $\begin{array}{l}\text { Determine the geographic origin of the animals } \\
\text { genetically. }\end{array}$ \\
\hline Collins, R. 2008 & $\begin{array}{l}\text { Sunda or greater slow } \\
\text { loris }\end{array}$ & Keep slow lorises in social groups. \\
\hline Streicher, U. 2004 & Pygmy slow loris & $\begin{array}{l}\text { Handle slow lorises carefully to prevent stress during } \\
\text { the rehabilitation period. }\end{array}$ \\
\hline Kenyon, M. 2014 & Pygmy slow loris & $\begin{array}{l}\text { Keep fewer slow lorises in quarantine cages, to } \\
\text { prevent parasites and spreading of diseases. }\end{array}$ \\
\hline $\begin{array}{l}\text { Moore, R.S. } 2012 \\
\text { Kenyon, M. } 2014\end{array}$ & $\begin{array}{l}\text { Javan slow loris } \\
\text { Pygmy slow loris }\end{array}$ & $\begin{array}{l}\text { Larger habituation cages prevent stereotypic } \\
\text { behaviour and increase survival success. }\end{array}$ \\
\hline Collins, R. 2008 & $\begin{array}{l}\text { Sunda or greater slow } \\
\text { loris }\end{array}$ & $\begin{array}{l}\text { Provide the lorises with their natural exudate-based } \\
\text { diet: including gum, live animals (to develop hunting }\end{array}$ \\
\hline $\begin{array}{l}\text { Nekaris, K.A.I. } \\
2015^{*}\end{array}$ & Slow loris ssp. & skills) and branches (to enhance gouging behaviour). \\
\hline $\begin{array}{l}\text { Moore, R.S. 2012, } \\
\text { Kenyon, M. } 2014 \\
\text { Collins, R. 2008, } \\
\text { Moore, R.S. } 2014\end{array}$ & $\begin{array}{l}\text { Javan slow loris } \\
\text { Pygmy slow loris } \\
\text { Sunda or greater slow } \\
\text { loris }\end{array}$ & $\begin{array}{l}\text { Provide pre-release enclosures with dense vegetation } \\
\text { with continuous pathways, away from antropogenic } \\
\text { activity and hiding/ sleeping places above the ground } \\
\text { to prevent disturbance by ground dwelling predators. }\end{array}$ \\
\hline $\begin{array}{l}\text { Moore, R.S. 2012, } \\
2014 \\
\text { Kenyon, M. } 2014 \\
\text { Moore, R.S. } 2014\end{array}$ & $\begin{array}{l}\text { Javan slow loris } \\
\text { Pygmy slow loris } \\
\text { Sunda or greater slow } \\
\text { loris }\end{array}$ & Make soft release a standard protocol. \\
\hline $\begin{array}{l}\text { Moore, R.S. } 2014 \\
\text { Kenyon, M. } 2014 \text {, } \\
\text { Streicher, U. } 2004 \\
\text { Moore, R.S. } 2014\end{array}$ & $\begin{array}{l}\text { Javan slow loris } \\
\text { Pygmy slow loris } \\
\text { Sunda or greater slow } \\
\text { loris }\end{array}$ & $\begin{array}{l}\text { Release slow lorises in a season where food is at a } \\
\text { maximum. }\end{array}$ \\
\hline $\begin{array}{l}\text { Nekaris, K.A.I. } \\
\text { 2015* }\end{array}$ & Slow loris ssp. & $\begin{array}{l}\text { Release small groups of slow lorises rather than } \\
\text { solitary animals. }\end{array}$ \\
\hline $\begin{array}{l}\text { Moore, R.S. } 2014 \\
\text { Moore, R.S. } 2014\end{array}$ & $\begin{array}{l}\text { Javan slow loris } \\
\text { Sunda or greater slow } \\
\text { loris }\end{array}$ & $\begin{array}{l}\text { Assess the population of wild slow loris species in the } \\
\text { release area. }\end{array}$ \\
\hline
\end{tabular}




\begin{tabular}{|c|c|c|}
\hline $\begin{array}{l}\text { Nekaris, K.A.I. } \\
\text { 2015* }\end{array}$ & Slow loris ssp. & \\
\hline \multirow[t]{2}{*}{$\begin{array}{l}\text { Moore, R.S. } 2014 \\
\text { Kenyon, M. } 2014 \\
\end{array}$} & $\begin{array}{l}\text { Javan slow loris } \\
\text { Pygmy slow loris }\end{array}$ & Assess the prevalence of predators in the release area. \\
\hline & & Post-release recommendations \\
\hline $\begin{array}{l}\text { Streicher, U. } 2004 \\
\text { Collins, R. } 2008\end{array}$ & $\begin{array}{l}\text { Pygmy slow loris } \\
\text { Sunda or greater slow } \\
\text { loris }\end{array}$ & $\begin{array}{l}\text { Provide a translocation area with dense vegetation } \\
\text { with continuous pathways, away from antropogenic } \\
\text { activity and hiding/ sleeping places above the ground } \\
\text { to prevent disturbance by ground dwelling predators. }\end{array}$ \\
\hline $\begin{array}{l}\text { Kenyon, M. 2014, } \\
\text { Streicher, U. } 2004\end{array}$ & Pygmy slow loris & $\begin{array}{l}\text { Release slow lorises in an area with the same climatic } \\
\text { conditions as their original habitat. }\end{array}$ \\
\hline \multirow[t]{2}{*}{$\begin{array}{l}\text { Moore, R.S. } 2012 \\
\text { Streicher, U. } 2004\end{array}$} & $\begin{array}{l}\text { Javan slow loris } \\
\text { Pygmy slow loris }\end{array}$ & $\begin{array}{l}\text { Post-release monitoring is needed both of the } \\
\text { released animal (compassionate translocation) as of } \\
\text { the release area (conservation translocation). }\end{array}$ \\
\hline & & General recommendations \\
\hline Collins, R. 2008 & Sunda or greater slow loris & $\begin{array}{l}\text { The team of keepers, researchers and local authorities } \\
\text { that is involved is small and communicates well as to } \\
\text { reduce stress for the animals during rehabilitation, } \\
\text { release and monitoring. }\end{array}$ \\
\hline $\begin{array}{l}\text { Moore, R.S. } 2012 \\
\text { Streicher, U. } 2003 \\
\text { Nekaris, K.A.I. } \\
2015^{*}\end{array}$ & $\begin{array}{l}\text { Javan slow loris } \\
\text { Pygmy slow loris } \\
\text { Slow loris ssp. }\end{array}$ & $\begin{array}{l}\text { Study behaviour and ecology of slow loris species in the } \\
\text { wild. }\end{array}$ \\
\hline Streicher, U. 2004 & Pygmy slow loris & $\begin{array}{l}\text { Even if slow loris species seem very similar, } \\
\text { recommendations for reintroduction can't just be } \\
\text { transferred between species. }\end{array}$ \\
\hline $\begin{array}{l}\text { Nekaris, K.A.I. } \\
2015^{*}\end{array}$ & Slow loris ssp. & $\begin{array}{l}\text { Use the knowledge from local communities about slow } \\
\text { lorises. }\end{array}$ \\
\hline $\begin{array}{l}\text { Nekaris, K.A.I . } \\
\text { 2015* }\end{array}$ & Slow loris ssp. & $\begin{array}{l}\text { Consult other studies and keep contact with } \\
\text { researchers, use similar methodologies for research to } \\
\text { collect data. }\end{array}$ \\
\hline
\end{tabular}

* Recommendations by Nekaris \& Starr 2015

Recommendations mentioned in at least three references were: (1) Provide the pre-release enclosures with dense vegetation with continuous pathways, away from anthropogenic activity and hiding/ sleeping places above the ground to prevent disturbance by ground dwelling predators. (2) Make soft release a standard protocol. (3) Release slow lorises in a season where food is at a maximum. (4) Study the behaviour and ecology of slow loris species in the wild.

\section{DISCUSSION}

This review paper aimed to make recommendations for rehabilitation and translocation of the slow loris species (Nycticebus ssp.) in Malaysian Borneo. A limitation could be that the slow loris species of the studies in this review are not native to Malaysian Borneo. However, the different species have a lot in common. The findings in the present paper could therefore still be valuable to the Bornean situation. Another limitation was that all the analyzed studies involve only small numbers of released animals. However, it was still useful to compare these studies to discover possible trends. Figure 2 compares the success of three translocation studies. The reintroduction of the Javan slow loris is most successful (Moore et 
al., 2014). Moore (2014) mentions a slight improvement of post-release survival of the Javan slow loris in his paper as well. The main difference between the Moore and Kenyon studies is the use of a large habituation cage in $50 \%$ of the releases of Javan slow lorises by Moore. A point of attention is that in wild populations a certain percentage of animals die, due to predation, hypothermia, lack of food, hunting etcetera. Goodman (1993) estimated death rates due to predation alone in Microcebus populations to be $25 \%$. The number of animals in wild slow loris populations that dies due to predation might also be high (Goodman et al.,1993). Assessment of predators in the release area is important because in the studies of Moore (2014) and Streicher (2003) a number of released animals died due to predation. Most predation of slow loris occurs when they are forced to move between trees on the forest floor. Ground cover in a large habituation enclosure and release area, and dense vegetation with continuous pathways well above the ground are therefore of major importance. Radio telemetry supplemented by direct observation seems to also be important. The animals spend time in thick vegetation, making direct observation impossible. Regarding the recommendations that were found, it is important to understand whether and how local workers want to participate in a research program.

In addition to the recommendations for rehabilitation and release, mentioned in the IUCN guidelines of 2002 and 2013, the following recommendations, some of which are also mentioned by the IUCN, are of interest to wildlife centres in Malaysian Borneo: (1) Study which slow loris species are rehabilitated in Bornean wildlife centres; (2) Study the behavioural characteristics of the captive slow lorises in Bornean wildlife centres; (3) Assess the wild slow loris species living in the release area; (4) Study the behaviour and habitat use of the wild population; (5) Assess what predators are present in the release area.

It might also be valuable to assess in a computer simulation what percentage of a natural population of slow lorises dies due to different factors such as old age, disease, weather conditions, predation and food conditions in their habitat.

Following these recommendations will hopefully lead to a better conservation of these beautiful species.

\section{Acknowledgements}

This paper benefited enormously from the contributions of the following people: $\mathrm{N}$. Beckerson and L. Biddle provided valuable information. V. P. J. Borm and M. Hopman-Rock greatly improved the quality of this manuscript. B.G. de Vries commented on the manuscript. I.E.E. Scheper provided valuable literature. Thanks to C. Voigt who shared the photo of Nycticebus sp. Additional thanks to one anonymous reviewer. 


\section{REFERENCES}

Beckerson, N. 2016. pers. comm. May 2016.

Beckerson, N. 2015. Slow lorises at Matang In: http://projectorangutan.com/blog Accessed on 13 April 2016.

Biddle, L. 2015. pers. comm. Dec 2015.

Browning, B. 2017. Pers. comm. April 2017

Collins, R., Sanchez, K.I. and Nekaris, K.A.I. 2008. Release of greater slow lorises, confiscated from the pet trade, to Batutegi Protected Forest, Sumatra, Indonesia. Global reintroduction perspectives. IUCN Reintroduction Specialist Group, Abu Dhabi, p 192-195.

Goodman, S.M., O'Connor, S. and Langrand, L. 1993. A review of predation on lemurs: implications for the evolution of social behaviour in small, nocturnal primates. In: Knapler, P. and Gandshorn, J. (eds) Lemur social systems and their ecological basis. Plenum Press, NY, pp 51-66.

International Animal Rescue, 2006. Rescuing primates and raptors in Indonesia. IAR Annual Review 2006: 18-21.

International Animal Rescue, 2008. Rescuing and rehabilitating primates in Indonesia. IAR Annual Review 2008: 10-12.

International Animal Rescue, 2011. Primate rehabilitation and release. IAR Annual Review 2011: 6-8.

International Animal Rescue, 2012. Primate rehabilitation and release. IAR Annual Review 2012: 8-9.

International Animal Rescue, 2013. Primate rehabilitation and release. IAR Annual Review 2013: 8-9.

International Animal Rescue, 2016. In: http://www.internationalanimalrescue.org/truthbehind-slow-loris-pet-trade Accessed on 27 March 2016.

Isler, K. and Thorpe, S.K. 2003. Gait parameters in vertical climbing of captive, rehabilitant and wild Sumatran orang-utans (Pongo pygmaeus abelii). Journal of Experimental Biology 206: 4081-4096.

IUCN (International Union for the Conservation of Nature), 2002. Guidelines for nonhuman primate re-introductions. Re-introduction News 21: 29-57.

IUCN/SSC (International Union for the Conservation of Nature/Species Survival Commission), 2013. Guidelines for Reintroductions and Other Conservation Translocations (Version 1.0). IUCN/SSC, Gland Switzerland. 
Kenyon. M., Streicher, U., Loung, H., Tran, T., Tran, M., Vo, B. and Cronin, A. 2014. Survival of reintroduced pygmy slow loris Nycticebus pygmaeus in South Vietnam. Endangered Species Research 25: 185-195.

Ligabue-Braun, R., Verli, H. and Carlini, C.R. (2012) Venomous mammals: a review. Toxicon 59: 680-695.

Moore, R.S. 2012. Ethics, ecology and evolution of Indonesian slow lorises (Nycticebus spp.) rescued from the pet trade. PhD thesis, Oxford Brookes University, Oxford.

Moore, R.S., Wihermanto, N.K. and Nekaris, K.A.I. 2014. Compassionate conservation, rehabilitation and translocation of Indonesian slow lorises. Endangered Species Research 26: 93-102.

Munds, R.A., Nekaris, K.A.I. and Ford, S.M. 2013. Taxonomy of the Bornean slow loris, with new species Nycticebus kayan (Primates, Lorisidae). American Journal of Primatology 75: 46-56.

Nekaris, K.A.I. 2014. Extreme primates: Ecology and evolution of Asian lorises. Evolutionary Anthropology: Issues, News, and Reviews 23: 177-187.

Nekaris, K.A.I., Rode, E.J., and Nijman, V. 2014. Javan Slow Loris Nycticebus javanicus É. Geoffroy Saint-Hilaire, 1812 Indonesia (2008, 2010, 2012). Primates in Peril: The World's 25, 2012-2014.

Nekaris, K.A.I. and Starr, C.R. 2015. Conservation and ecology of the neglected slow loris: priorities and prospects. Endangered Species Research 28: 87-95.

Rode-Margono, E.J. and Nekaris, K.A.I. 2015. Cabinet of curiosities: venom systems and their ecological function in mammals, with a focus on primates. Toxins 7: 2639-2658.

Shepherd, C.R., Sukumaran, J. and Wich, S.A. 2004. Open season: an analysis of the pet trade in Medan, North Sumatra, 1997-2001. TRAFFIC, Southeast Asia, Petaling Jaya, Selangor.

Streicher, U. and Nadler, T. 2003. Re-introduction of pygmy lorises in Vietnam. Reintroduction News 23: 37-40.

Streicher, U. 2004. Aspects of ecology and conservation of the pygmy loris Nycticebus pygmaeus in Vietnam. PhD thesis. Ludwig-Maximilians Universität, Munich. 